\title{
Improving the developmental impact of multinational enterprises: policy and research challenges
}

\author{
Rajneesh Narula ${ }^{1}$ (D) André Pineli ${ }^{1}$
}

Received: 9 October 2018 / Revised: 22 October 2018 / Accepted: 24 October 2018 /

Published online: 29 October 2018

(C) The Author(s) 2018

\begin{abstract}
We summarize the key empirical evidence on the nexus between MNEs and development, focusing on issues that are relevant for the formulation, implementation and assessment of policies by host developing countries. We also delve into what we do not know, as well as topics for which the evidence is still quite blurred. We discuss the reasons for the absence of clear evidence, and potential avenues for future research to improve policies. Although most countries rely on MNEs/FDI as a central plank of their development strategy, the collective weight of academic research has not led to a fine-tuning of policy implementation. Countries still rely on policies for which evidence is sparse, or no longer valid in an era of globalisation. Much of the literature has focused on externalities and spillovers, and has deemphasised the other 'effects' of MNE activity, implicitly assuming that MNEs are almost always beneficial for development. Few rents are costless when the opportunity costs of scarce resources are considered, especially in the longer term. Despite the abundance of empirical studies (of increasing sophistication), most ignore the significance of structural change. Growth and the interaction with MNE activity is not linear or monotonic over time, because the economy itself is in a constant state of flux.
\end{abstract}

Keywords Multinational enterprises · Economic development · Developing countries · GDP growth $\cdot$ Spillovers $\cdot$ Public policy

JEL Classification D62 · F23 · O14 · O19 · O24 · D62

Rajneesh Narula

r.narula@reading.ac.uk

1 Henley Business School, University of Reading, Reading, UK 


\section{Introduction}

The role of multinational enterprises (MNEs) as catalysts of economic development came to the forefront of development policy thought no more than fifty years ago. A landmark of this "novel" view was a 1973 United Nations' report titled Multinational Corporations in World Development. According to its preface,

The United Nations Economic and Social Council, [...] requested the Secretary-General to appoint a Group of Eminent Persons to study the role of multinational corporations and their impact on the process of development, especially that of developing countries, and also their implications for international relations; to formulate conclusions which may possibly be used by governments in making their sovereign decisions regarding national policy in this respect, and to submit recommendations for appropriate international action. [...] In conclusion, the report reviews existing policies in respect of multinational corporations and includes proposals for national, regional and international action. (UNDESA 1973, p. vi).

Although few today have read this report in its original form, the issues it raises and the fundamental challenges it outlines, remain contemporary concerns. This report proved inspirational in many circles. Almost all of the challenges then outlined have come to shape the policy and academic debate in both Economics and International Business (IB), and through organizations such as the UN Centre for Transnational Corporations (now UNCTAD's Division on TNCs), into policy discussion.

The fact that understanding the role of MNEs in development remains a contemporary issue within research areas such as economics, finance, sociology, ethics and management studies indicates the growing importance of MNEs, and their capacity to inflict change, both positively and negatively. We currently know that MNEs can be engines for knowledge transfer, capital deepening, employment and structural change, but their investments can also be a double-edged sword. Through their actions, both active and the unintentional, MNEs may also produce adverse effects in host countries. They can be anti-competitive, and instead of promoting growth within a sector, they may simply "hollow-out" entire sectors of (weaker) domestic firms. Quoting the United Nations' report once again " [...] the power concentrated in their hands and their actual or potential use of it, their ability to shape demand patterns and values and to influence the lives of people and policies of governments, as well as their impact on the international division of labour, have raised concern about their role in world affairs" (UNDESA 1973, p. 2 ). These concerns remain as relevant today as they did in the early 1970s.

Policies towards MNEs were a central concern of the foundational work that gave birth to the field of IB studies as a separate discipline. Discussions about government-foreign investor relations and the scope for international regulation of foreign direct investment (FDI) were key issues in the research agenda during the 1970s (UNDESA 1973; Sagafi-Nejad 2008). However, while the MNEs have become the hallmark of globalisation, and the importance of MNE-assisted 
development now a mainstream plank of almost every country's development strategy, these policies do not reflect that there are a number of important caveats from the empirical literature. Broadly speaking, most development and FDI policy has not taken into account that the dynamics of FDI and development have evolved, and the presence of MNE investment is still not a sine qua non for development. If successful outcomes of FDI-assisted development were the norm, this faith in the power of the MNE would be justified. On the contrary, numerous relevant matters remain controversial, and only a handful of countries have used a FDI-driven development successfully.

The fact is that a burgeoning empirically-driven economics-related literature has tackled the subject with great zest, although the collective weight of these findings has not led to a fine-tuning of policy implementation. In this paper, we bring together a variety of issues that are relevant for the formulation of policies related to MNEs, and to assess their impact on the economic development of host economies (with a particular focus on the developing countries). Our intention here is, on the one hand, to highlight what scholarship in the area knows with a satisfying degree of certainty. On the other hand, we will also delve into what we do not know, as well as topics for which the evidence on the matter is still quite blurred. The analysis we do here is not a purely intellectual one: the economics literature increasingly informs policy studies done by a variety of national governments and supranational agencies (such as UNCTAD, OECD, ASEAN, EU), and itself draws on theoretical contributions from the economics of IB. Secondarily, we are also concerned that a number of insights from these economics studies do not always find their way back into the academic literature in IB and do not always inform new developments in international business theory, or to policy implementation in developing countries. Finally, by identifying the weaknesses in the economics-focused empirical literature, we are able to suggest areas for future research.

We examine two aspects of the literature: the microeconomic literature, which is strongly centred on the analysis of FDI spillovers and the macroeconomic literature, which is mostly focused on the FDI-GDP growth relationship. Although they are clearly related, as noted elsewhere, there is a certain degree of ambiguity between the micro and the macro evidence (Narula and Driffield 2012) and sometimes reach discrepant conclusions. They will therefore be discussed separately, what means that inevitably there is some overlap. We do not intend to be exhaustive on the wide empirical literatures in both streams as our focus is on findings that can be informative to policy-making in developing countries.

Much of the literature has focused on externalities and spillovers, and deemphasised the direct effects of MNE activity, taking as an implicit assumption that MNEs are almost always beneficial for development. Yet, despite the abundance of empirical studies (of increasing sophistication), in many respects the evidence continues to be ambiguous, with more areas of doubt than certainties. To avoid being repetitive, most recommendations for further research are presented together with the discussion of the extant literature. We conclude by offering some observations about the reasons for the absence of clear evidence, and some of the most pressing challenges facing researchers today. 


\section{An overview of the empirical literature with a focus on policy-relevant issues}

The attraction of MNEs, through foreign direct investment (FDI) or other forms of engagement, has become a key component of development policy in most developing countries. MNEs are viewed as a means to break the vicious circle of underdevelopment, characterized by low savings and investment ratios and inefficient production methods and technologies. MNEs are deemed able to provide a comprehensive package that includes not just financial resources but also technology, managerial know-how and, in some cases, linkages to value chains (UNCTAD 2013; Narula 2014b; Narula and Pineli 2017). Governments across the world offer generous bundles of subsidies in order to woo MNEs.

Governments tend to view MNEs as better equipped with many of the attributes (ownership advantages) that improve a country's productivity as compared to domestic firms. They also expect that the presence of foreign MNEs will give rise to spillovers of various kinds to domestic actors. Hence, attracting FDI is viewed as a means to accelerate GDP growth while contributing to the transformation of the employment and production structures of the economy. This set of beliefs leads governments to actively engage with foreign investors to influence the volumes and composition of FDI and (to a lesser extent) to maximize the fulfilment of the expected secondary effects.

Unfortunately, there is as yet no consensus on the proper ways to evaluate the effects of MNEs' engagement in host economies. The academic literature centres around two approaches, each one with their own strengths and weaknesses.

\subsection{The microeconomic literature}

The microeconomic approach to the impact of FDI in host countries have largely revolved around the assumption that the presence of foreign investors generates spillovers to domestic players, implicitly taking for granted that the direct effects of FDI are always positive. This is due to the fact that foreign affiliates generally perform better than domestic firms. Studies focused on foreign acquisitions such as Arnold and Javorcik (2009) and Liu et al. (2017) confirms that the transfer of ownership fosters the productivity of the acquired firms. However, the cause of the performance gap is not the nationality per se. MNEs and domestic firms differ in a number of issues, most of which can be summarized in the concept of ownership advantages (Dunning 1988), and these largely explain the performance differentials. ${ }^{1}$

The main indirect effects (potentially) generated by MNEs in host countries are shown in Fig. 1. If these effects are predominantly positive, a larger presence of foreign MNEs would impact favourably the productivity of domestic firms, be they competitors, suppliers or buyers of the foreign MNEs. These effects would

\footnotetext{
${ }^{1}$ For a comprehensive review of the empirical literature on the performance differences between domestic and foreign-owned firms, see Bellak (2004).
} 


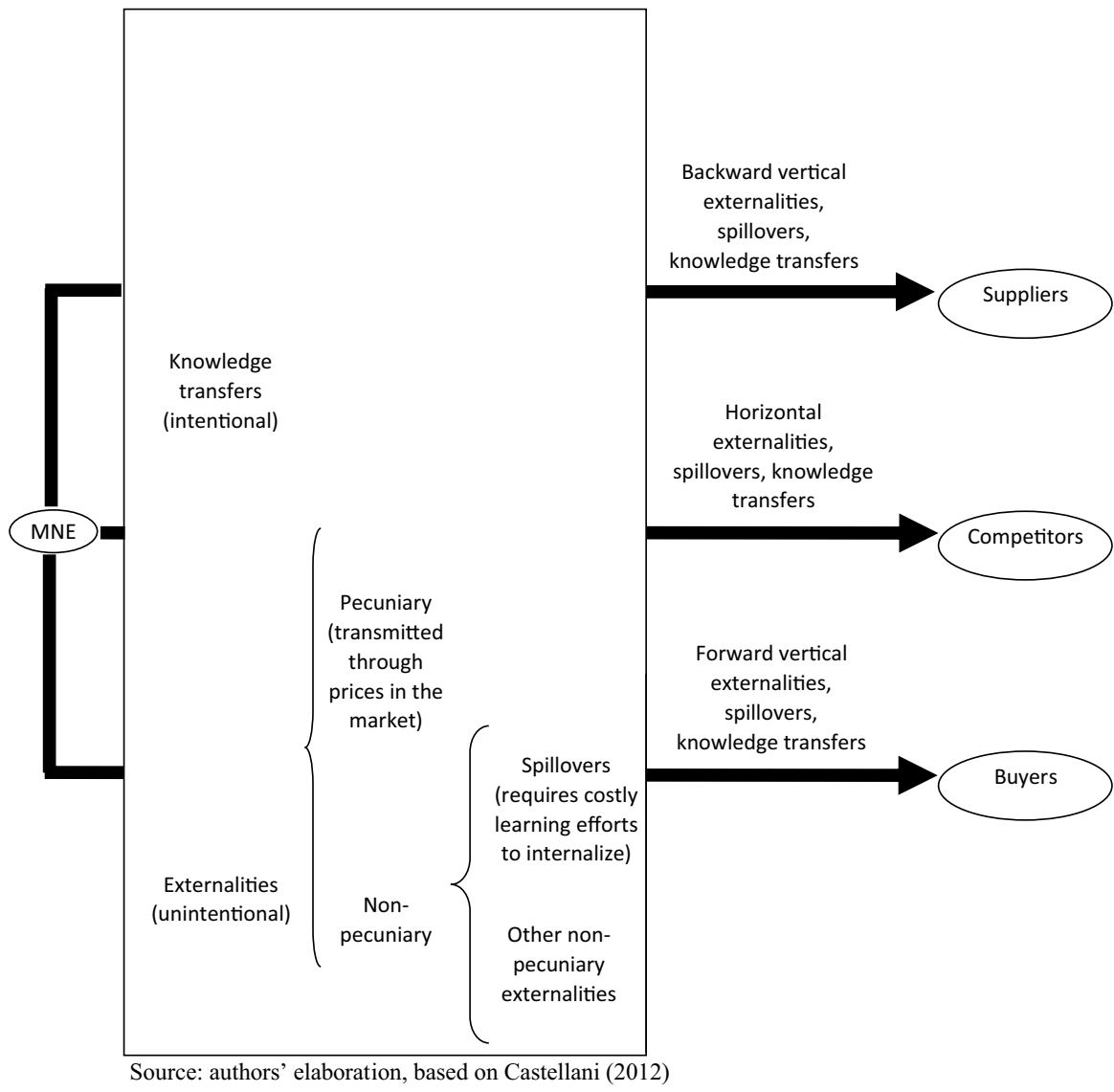

Fig. 1 Indirect effects of MNEs' presence in host countries. Source: authors' elaboration, based on Castellani (2012)

materialize through four main channels: competition effect, demonstration/imitation effect, labour turnover effect, and backward and forward linkages (see Table 1).

After a flood of empirical studies, ${ }^{2}$ it seems today that most of the low hanging fruit have already been reaped by researchers, but this does not mean that all the controversies have been solved. On the contrary, meta-analyses of studies on FDI productivity spillovers (Meyer and Sinani 2009; Havranek and Irsova 2011; Irsova and Havranek 2013) had shown weak regularity in terms of estimated effects, with the only exception being the general negligible effects of the presence of

\footnotetext{
2 This stream of literature had its apex in the first decade of the 21 st century, when firm-level longitudinal databases became available not only among developed countries, but also in many developing economies. Improved data allowed the use of more appropriate econometric methods than those used by pioneer studies about FDI spillovers, such as Caves (1974), which relied on cross-sectional industry-level data.
} 
Table 1 Channels of FDI externalities. Source: authors' elaboration

\section{Competition effects}

In both product and input markets, including labour and financial markets

The level of monopoly power (due to brands, technologies, access to foreign resources etc.) enjoyed by foreign MNEs is likely to affect the chances of occurrence of crowding-out or crowding-in

Dominated by pecuniary externalities

\section{Demonstration/imitation effects}

These account for a majority of spillovers

\section{Labour turnover effects}

Managerial and technical know-how accumulated during work experience in MNEs are transferred by workers when they move to another firm, or start a new one

Most often are pecuniary externalities, since salaries tend to reflect part of the knowledge "embedded" in moving workers

\section{Forward and backward linkages}

Often pecuniary externalities, affecting not only suppliers and buyers, but competitors since they can benefit, for example, from lower input prices induced by higher scales of production

Empirically difficult to distinguish real spillovers from (intentional) knowledge transfers

foreign MNEs on the productivity of their competitors (horizontal spillovers). Vertical spillovers seem to vary considerably across countries, but they tend to be positive and economically significant when it comes to supplier industries (backward spillovers), whereas the effects on buyer industries (forward spillovers) are economically irrelevant on average.

Over the years, a number of relevant points have been raised about the studies on FDI productivity spillovers. First, data limitations and the most widely used estimation methods impose the adoption of some unrealistic assumptions that may compromise the results. To cite a few: the use of accounting data imposes the use of dubious deflators to "turn value data into quantities"; the infrequent updating of countries' input-output matrices impedes the investigation of the dynamic effects of FDI on the input-output structure, obliging the researcher to assume that the economic structure remained the same over the period under analysis; the non-differentiation between foreign-invested and domestic firms in input-output tables impose the assumption that both groups share identical procurement patterns, probably leading to overestimation of local sales and purchases of MNEs. In addition, using incomplete datasets biases the estimations. Small domestic firms are also less likely to be covered by national industrial surveys than large firms. The problem is further magnified when the studies are based on datasets such as Compustat, which has a poor coverage of small firms. This sample selection problem not only causes an overestimation of the foreign presence in a given industry but also introduces an upward bias in the estimation of the true spillover effects as shown by Eapen (2013).

Second, disentangling the channels through which spillovers are assumed to occur has proven very difficult in practice. However, such differentiation has important implications for policy. In the case of China, for example, $\mathrm{Lu}$ et al. (2017) found that proximity to MNEs induce positive productivity spillovers to domestic 
competitors, sometimes compensating for the detrimental effect caused by stronger competition.

Third, it has become clear that a substantial share of the effects captured by econometric estimates are likely not 'true' spillovers, but pecuniary externalities (Castellani 2012). Pecuniary externalities occur when actions taken by an economic agent affect other agents through changes in market prices. They differ from nonpecuniary externalities, which are not transmitted through the market (Castellani 2012). The arrival of an MNE in a host country is likely to produce a set of pecuniary externalities, since its presence may affect both the markets for inputs (including labour markets) and outputs. As such, they are not prone to be affected by policy. In addition, econometric studies are usually unable to distinguish between actual knowledge spillovers (which is an unintended consequence of the foreign presence) and intentional knowledge transfer from MNEs to their suppliers and customers, even though this distinction is very relevant for policy matters. Although many scholars use the terms 'spillover' and 'externality' as synonyms, a distinction can be made between effects that require costly processes of internalization by the recipient firm (spillover) and those that do not. In summary, this means that all spillovers are externalities, but not all externalities are spillovers (Narula and Driffield 2012).

In the face of these difficulties, there seems to have been a relatively recent shift of FDI spillovers studies towards more easily-or less controversially-measured outcome variables, such as the entry, survival or exit of domestic firms, or their propensity (and intensity) to export and innovate, but the diversity of findings persists (a summary of the empirical approaches is presented in Table 2). With respect to survival odds of domestic firms, there is indication of crowding-out in Vietnam (Kokko and Thang 2014), crowding-in for the Czech Republic (Ayyagari and Kosova 2010) and no effect at all in Turkey (Taymaz and Ozler 2007; Ferragina 2014). The impact seems to vary over time. In Czech Republic, crowding-out prevailed in the shortrun, due to increased competition, but as time allowed knowledge spillovers to take place, crowding-in became the norm (Kosova 2010). Whatever the case, we must bear in mind that crowding-out is not a problem per se. Indeed, fiercer competition is expected to lead to "natural selection" of the most appropriate firms. If the new players are simply displacing the least efficient competitors, the outcome can hardly be viewed as adverse. Furthermore, the entry of more competitive firms in the market can benefit domestic firms in upstream industries. This is precisely what has been observed in Czech Republic and Vietnam (Ayyagari and Kosova 2010; Kokko and Thang 2014), where the survival odds of domestic firms are enhanced by the presence of MNEs in downstream industries, thus corroborating the findings of FDI productivity spillovers literature (which indicates that the presence of MNEs are likely to enhance the productivity of domestic firms in supplying industries).

With respect to both export and innovation spillovers, the available evidence is more favourable to FDI, or at least is less blurred than in the case of productivity spillovers. The occurrence of FDI export spillovers has been identified in countries as diverse as Chile (Duran and Ryan 2014), China (Chen et al. 2013), Poland (Cieslik and Hagemejer 2014) and Vietnam (Anwar and Nguyen 2011). In contrast to productivity spillovers studies, FDI seems to be positively associated with the propensity and intensity of exports of domestic firms in the same 
Table 2 The four main categories of studies on FDI spillovers. Source: authors elaboration

\section{Productivity spillovers}

A very indirect way to analyse how the presence of foreign MNEs affect domestic firms

The usual empirical specification does not permit distinguishing between knowledge transfers, pecuniary externalities and actual spillovers

The channels through which the externalities take place are seldom taken into account since the information about MNEs is usually restricted to their share in industry value added or turnover.

Despite these shortcomings, productivity is by far the most used dependent variable in FDI spillovers studies

\section{Survival/exit/entry of domestic firms}

A straightforward way of investigating the secondary effects caused by MNEs' presence on domestic economy, particularly when looking for crowing-out/crowding-in effects

Much less dependent on data quality, but dependent on a high coverage of the universe of domestic firms, particularly the smaller ones, for a time period lengthy enough as to reveal the dynamics of firm creation and closure

\section{Innovation spillovers}

This category suffers from some of the problems faced by FDI productivity spillovers, such as the non-distinction between knowledge leakage (externality) and knowledge transfer and the non-identification of the channels of externalities, but it employs measures such as innovation propensity and intensity which are less problematic than (total factor) productivity

\section{Exporting behaviour/spillovers}

Recent studies in this category waived simple measures of foreign presence (such as MNEs' share in industry value added), using instead data on MNEs' exporting behaviour to trace its effect on domestic firms' propensity to export, export intensity, entry in new markets and new product lines

The wealth of details and the high levels of disaggregation of customs data have allowed clearer identification of causality mechanisms in comparison to other categories of studies

industry, an expected result since fiercer competition tend to put the mechanisms of natural selection in motion. In the case of China, it was found that the presence of foreign MNEs increases the probability of domestic firms' initiation on a new export market (identified by product-destination) (Mayneris and Poncet 2015) and the survival odds of an export market (Swenson and Chen 2014). Furthermore, the positive influence was found to be more relevant for penetrating in "difficult" markets, defined as countries with poorer institutional quality and/or tougher import procedures (Mayneris and Poncet 2011).

As in the exporting case, the available evidence supports the occurrence of FDI innovation spillover effects. The innovative performance (measured by new product sales per employee) of domestic Chinese firms seems to be positively associated with R\&D expenditures of foreign MNEs in the same high-technology sector (Liu and Buck 2007). The importance of horizontal spillovers was corroborated by Ito et al. (2012), who failed to find effects of FDI in upstream or downstream industries on patenting application by Chinese domestic firms. According to $\mathrm{Hu}$ and Jefferson's (2009) estimations, horizontal spillovers had almost the same explanatory power as domestic firms' own R\&D efforts in explaining the patenting propensity of large and medium sized Chinese domestic firms in the period 1995-2001. Nonetheless, despite the consistency of such results, we 
must be cautious about generalising from the case of China. China is unique in many respects, politically, sociologically and economically. Its absolute size and the related prospects of scale economies means that no other country has the bargaining power of China vis-à-vis MNEs. Furthermore, although China, like other developing countries, remains a strongly dual economy, the "advanced" parts of its economy are large in absolute terms and growing quickly in relative terms. Key indicators for development prospects such as the ratio of research and development (R\&D) expenditure to GDP show China much closer to the advanced economies than to the developing world-in 2015, the figures were $2.07 \%$ for China, 2.55\% for OECD members and less than 1\% for almost all developing countries (World Bank 2017). Therefore, the replication of China-based research in different contexts is needed to confirm the soundness and extendibility of those findings.

\subsection{What does the FDI spillovers literature tell us about policy-related issues?}

The mixed results found in the literature suggest that FDI spillovers are bound to be a context-specific phenomenon. The potential for spillovers only materialize under certain conditions. In terms of policy relevant issues, what have we learned from this huge spillovers literature?

We must stress that when we refer to domestic firms in developing countries we are talking about a very heterogenous group. Wide productivity differentials are easily found not only across sectors, but also across industries of the same sector and even across firms of the same industry. The coexistence of a few large firms with a myriad of very small firms in the same industry is rather common (Tybout 2000). Thus, overall productivity in developing countries is often low, as most plants operate well below efficient scales. In addition, a large fraction of these firms operates at the margins of the formal sector. Indeed, upwards of $90 \%$ of Indian manufacturing firms operate in the informal sector. Informal firms tend to not only have low productivity, but have low prospects of expanding, as they do not have access to regular credit markets to finance their growth.

The ability to "internalize" the spillovers generated by the presence of MNEs is not uniformly distributed across domestic firms. On the contrary, capturing spillovers is costly (Narula and Driffield 2012) and usually requires specialized workers, what is often in short supply in developing countries. Indeed, although most spillovers studies that have included some proxy to domestic firms' absorptive capacity ${ }^{3}$ have focused on developed countries, the evidence suggests that this factor is relevant in the developing country context as well. In general, firms with higher absorptive capacity are more likely to benefit from the presence of MNEs (Blalock and Simon 2009; Narula and Marin 2003; Castillo et al. 2014). Therefore, policies aimed at improving the absorptive capacity of domestic firms are likely to increase the chances of positive FDI spillovers. These include not only investments in formal

\footnotetext{
3 Absorptive capacity can be defined as "ability to internalise knowledge created by others and modifying it to fit their own specific applications, processes and routines” (Narula and Marin 2003, p. 23).
} 
education and vocational training, but also incentives to engage in $R \& D$, and the reduction of impediments to the free flow of knowledge, whether embodied in goods (such as imported capital goods) or otherwise.

If domestic firms' heterogeneity matters, so should the heterogeneity of MNEs. Indeed, MNEs are not all equal. The potential for linkages creation and spillovers depends on the nature of the investing MNE, although empirical studies often ignore this. A firm that internationalizes to sell more will behave very differently from a firm that internationalizes to reduce costs, and the development outcomes in the host economies will probably differ accordingly. Notwithstanding the theoretical support for the importance of FDI motives (Cuervo-Cazurra et al. 2015), the empirical evidence on their relationship with spillovers is intriguingly scarce (Driffield and Love 2007; Morrissey 2012). We consider that this remains an important gap in the empirical literature that needs to be addressed, although we recognize that identifying investment motives from official records is not trivial. Nonetheless, some evidence on the theme can be found in Merlevede and Schoors (Unpublished), which verified that, in Romania, backward vertical FDI spillovers were generally positive, but were significantly bigger among export-oriented industries. In principle, indirect evidence on this matter might also be extracted from differences in spillover effects related to the MNEs' countries of origin, but this variable is likely to reflect a handful of other characteristics such as procurement practices and preferences for more/less centralized decision-making. In a study on Vietnam, Ni et al. (2015) found positive backward vertical spillovers forged by investors from East Asian countries, except Japan and Korea. According to authors, this discrepancy is due to the tendency of Japanese and Korean investors to minimise local procurement. A study using Romanian data (Javorcik and Spatareanu 2011) found that investors from relatively distant countries (US) exerted a positive effect on the productivity of domestic firms in supplying industries, whereas investors from closer countries (European Union) did not. The authors argued that this difference related to the higher probability of transferring knowledge due to larger geographical distance (which affects transportation costs) and the existence of preferential trade agreements with the EU, which reduced the import tariffs and thus the incentives to search for local suppliers. Although it is not easy to draw policy recommendations from the findings above, host countries' governments should bear in mind that the potential benefits are not equal across investors from different countries of origin. In the same way, past successes in terms of spillover generation are not reliable guidelines of future outcomes, if key characteristics of the new investors differ substantially from the characteristics of the previous investors.

MNE subsidiaries are not unchanging in their nature. Indeed, we know that the mandate granted to the subsidiary by the headquarters evolves over time. Thus, the degree of autonomy conceded to the subsidiary is likely to change. Theoretical literature has underlined the marked differences between "competence-exploiting" and "competence-creating" subsidiaries, the former concentrating in exploiting existing assets of the whole MNE in the host country, while the later receive or gain mandates to perform asset augmenting activities, such as development of new products or new technologies, which can be later incorporated to the whole company's assets (Cantwell and Mudambi, 2005). The degree of embeddedness 
of competence-creating subsidiaries in the local environment, including the host country's national innovation system, is likely to be much higher than in the case of competence-exploiting subsidiaries (Narula 2014a). Hence, the potential for both knowledge spillovers and technological transfers seems to be much bigger within the universe of competence-creating subsidiaries than in the competenceexploiting case. Corroborating this hypothesis, Jindra et al. (2009) found that subsidiary's autonomy, initiative and technological capability was positively related to the extent of backward linkages (measured by the share of inputs bought from domestic suppliers) they created in four European transition economies. Nonetheless, few empirical studies have taken this important distinction into account when estimating FDI spillovers, but the results seem to corroborate the hypothesis that competence-creating and competence-exploiting MNE's subsidiaries produce different development outcomes in host economies. For India, Marin and Sasidharan (2010) found that only competence-creating subsidiaries (identified by high R\&D expenditure and export intensity) generated positive horizontal spillovers. Likewise, Todo and Miyamoto (2006) found that only MNE subsidiaries that performed R\&D locally generated significant positive horizontal spillovers in Thailand. For Argentina, the evidence is mixed: while Marin and Bell (2006) found that only technologically active subsidiaries generate positive spillovers, Chudnovsky et al. (2008) did not find any influence of the subsidiaries' degree of innovativeness on the overall negligible FDI spillovers to domestic firms. However, it must be stressed that all these studies focused on productivity measures, instead of more direct measures of innovation effort or outcome. An exception is Ha and Giroud (2015), who found that innovation performance of South Korean domestic firms (measured by patent counts) was positively affected by the presence of competence-creating subsidiaries of MNEs, and negatively by competence-exploiting, in buyer industries, while in supplier industries the effect was exactly the opposite. Therefore, it seems clear that more studies are needed to verify to what extent subsidiaries' heterogeneity matters for development outcomes. The policy relevance of the theme is straightforward, since incentives to $\mathrm{R} \& \mathrm{D}$ are among the few industrial policy tools that remained largely untouched by multilateral regulations.

The imposition of performance requirements to MNEs subsidiaries has been in developing countries' toolbox of industrial policy for several decades. They were central in import substitution strategies, but have survived, into the 21 st century, and indeed are considered to be going through a renaissance (UNCTAD 2018). However, a number of scholars have tended to be sceptical on the theme. Gorg and Greenaway (2004), for example, view performance requirements doing little to amplify the development outcomes of FDI, compared with less interventionist government policies such as investments in education and training. Moran (2011) strongly condemned all sorts of requirements, from local content requirements to joint venture mandates, on the basis that they lead to inefficiencies and prevent the transfer of the most valuable intangible assets from the parent to the affiliate, thus reducing the potential for spillovers. However, the effectiveness of performance requirements remains an unresolved question. They are often blamed by the poor 
economic performance of Latin America since the 1980s, but at the same time they cannot be dissociated from the Chinese growth miracle in the same period.

It is worth noting that we need to acknowledge the trade-offs involved when examining the spillover effects of performance requirements. The governance mode seems to play a role in the extent of spillovers. Available studies indicate that positive spillovers are more likely to occur in industries where joint ventures are more prevalent. This was confirmed for the cases of China (Abraham et al. 2010) and Romania (Javorcik and Spatareanu 2008), although for Indonesia no difference was detected (Blomstrom and Sjoholm 1999). Nonetheless, we should underline that, in general, empirical studies simply test the differential effect of joint ventures vis-àvis wholly-owned subsidiaries, disregarding whether they were imposed by the host country government or not. In relation to the importance of the technological gap between MNEs and domestic firms, the evidence is mixed. For Romania, Lenaerts and Merlevede (2014) found that while relatively more productive MNEs generated positive backward productivity spillovers to domestic firms, less productive MNEs generated negative spillovers. However, a different picture was presented by $\mathrm{Ni}$ (2016), who found that backward spillovers in Vietnam were bigger when the foreign investor had a middle-level total factor productivity, after controlling for the absorptive capacity of the domestic firms, what suggests the existence of hurdles to knowledge diffusion from more productive MNEs, presumably users of more advanced technology.

As for the effects of domestic content requirements, the empirical literature on FDI spillovers is almost silent, although there are a number of case studies and anecdotal data that provide some evidence in this regard. Part of the problem is the absence of a counterfactual: it is not easy to estimate what would be the FDI spillovers if the local procurement requirement was not in place. Exploring the effects of changes in policy is also difficult because the estimation of vertical spillovers relies on input-output tables which are updated only after long time intervals. ${ }^{4}$

In terms of country level determinants of FDI spillovers, our knowledge is still based, to a large extent, on meta-analyses of single-country studies. Given that estimation methods, data quality, time coverage, and control variables (among other factors) vary considerably across studies, affecting considerably the size and the significance of the spillover coefficient (Wooster and Diebel 2010), the results of meta-analyses must be taken with a grain of salt, particularly because they pool together studies on developed and developing countries. Meta-analyses employing different estimation methods yield quite different results. For example, Meyer and Sinani (2009) found that greater trade openness is associated to higher positive horizontal spillovers, while Irsova and Havranek's (2013) findings suggest precisely the opposite. In respect to backward vertical spillovers, Havranek and Irsova's (2011) results indicate that they are more likely to occur in countries more open to trade

\footnotetext{
4 Although this kind of limitation could be overlooked in an ordinary spillover study without seriously compromising the analysis, the same cannot be said if the purpose of the study is to investigate how domestic content requirements affect the occurrence of (vertical) spillovers since the explicit target of such a policy is precisely to modify the input-output relationships of an economy.
} 
and in countries with a lower level of financial development (measured by credit to the private sector/GDP). Diverging results about the influence of intellectual property rights protection on FDI productivity spillovers were found by Havranek and Irsova's (2011) and Irsova and Havranek's (2013) meta-analyses, and Smeets and de Vaal (2016), who pooled firms from 17 developed countries in a traditional (single-country) spillover regression augmented with country-specific IPR protection interaction terms. Meta-analyses revealed no effect of IPR protection on backward spillovers and an inverse relationship in the case of horizontal spillovers. In turn, Smeets and de Vaal (2016) results indicate that IPR protection strengthen backward spillovers, but weakens forward spillovers, whereas has no effect on horizontal spillovers. In face of the conflicting results, it is hard to draw any conclusion about the impact of all these factors on the strength of FDI spillovers. Nonetheless, we can underline that some of the results-for example, the negative relationship between financial development and backward spillovers, which suggests that foreign MNEs helps invested countries to alleviate financial constrains - are in clear contradiction with findings of the macroeconomic literature on the impacts of FDI. Therefore, one interesting area for future is research is the decomposition of macroeconomic findings.

Given all these aspects, it is hard to state emphatically what kind of FDI would provide sufficient returns to compensate for the incentives governments frequently offer. It is curious to us why the widespread practice of using cost/benefit analysis of projects (and the careful study of direct impacts), both by national and international agencies (e.g. Reddaway et al. 1968) and academics (Reuber 1973; Lall and Streeten 1977), was largely abandoned in favour of a perspective that views FDI as (almost) always beneficial to the host economy. Even without putting this assumption into question, we believe that the joint estimation of both the direct and indirect impacts of FDI would reveal important nuances that have been overlooked. This is precisely the approach adopted by Girma et al. (2015), who using firm-level data jointly estimated the direct and spillover effects of the presence of foreign MNEs on the productivity of region-sector clusters in China. Their results indicated that the direct effects are positive and increase as the MNEs' share rise (except when the MNE's share is below 10\%), while the indirect effect on domestic firms is negative, reaching the strongest impact when the foreign share is around $40 \%$ in the cluster. The overall effect on productivity is positive, but not monotonically related with foreign presence. The marginal negative spillover (i.e., indirect) effect outweighs the positive marginal direct effect up to a $20 \%$ foreign share. After this point, the direct effects become dominant. We think that there is much scope for further studies adopting a similar approach.

\subsection{The macroeconomic literature}

The macroeconomic approach seeks to identify a causal relationship between FDI flows or stocks and a macroeconomic variable, usually aggregate economic growth. Most studies have found a positive correlation between FDI and GDP growth, particularly among developing countries. Nonetheless, such an association might not 
be taken for granted. On the contrary, they are likely to depend on a few key characteristics of host countries. It must be underlined that these cross-country growth studies are not able to distinguish the direct effects from the spillover effects of FDI, although some of the moderating factors are believed to affect mainly the indirect effects. However, even in this case, it is impossible to detect whether horizontal or vertical externalities contribute more to the outcome.

An early finding of Balasubramanyam et al. (1996) was that FDI would be growth enhancing only if countries had an outward oriented development strategy, what means that countries that persisted in strategies centred on import substitution policies would not reap the alleged benefits of FDI (see also Lall 1996 and Dunning and Narula 1996). Other studies suggested that the materialization of the potential benefits of FDI were conditional on countries having reached a minimum level of human capital (Borensztein et al. 1998) and of financial development (Alfaro et al. 2004; Durham 2004). The policy implications of those findings were rather clear, even though the capacity to undertake the necessary remedial action varied across the developing world. However, later studies pointed out that many of these initial results were not as robust as they seemed to be, for several reasons. Firstly, omitted variable bias was a relevant matter. Much of this literature seemed to ignore what motivates FDI. ${ }^{5}$ Although the requirement of minimum levels of human capital is easily justified on theoretical grounds (Abramovitz 1986; Cohen and Levinthal 1989; Criscuolo and Narula 2008), the empirical evidence is less convincing when FDI motives are not controlled for. Indeed, MNE activity aimed at extracting natural resources has different development effects, from, say, market-seeking investments. FDI in countries with low levels of human capital or financial development (but with comparative advantages in natural resources) is likely to be concentrated in the extractive or natural resource-intensive sectors, and this aspect cannot be dissociated from the development outcome. Not only does MNE activity in the extractive industry tend to develop in enclaves, thus limiting the scope for linkages of MNEs with the domestic economy, it is also prone to all the consequences encompassed by the concept of natural resource curse (Auty 1994; Venables 2016; Narula 2018a). In short, FDI of different kinds yields different potential development effects.

In addition, Carkovic and Levine (2005) suggested that most previous findings were undermined by further econometric problems. After controlling for simultaneity bias and country-specific effects, they not only found no effect of FDI on GDP growth, but also found that this lack of impact was independent of the stock of human capital (a key indicator of absorptive capacity) or the financial development of the country. At a macroeconomic level, there is crescent doubt about causality mechanisms between FDI and GDP growth. There has been increasing evidence that this literature, as well as the whole cross-country growth literature, is plagued

\footnotetext{
5 A detailed discussion about the motives that lead an enterprise to invest abroad is beyond the scope of this research note (see, for this matter, Cuervo-Cazurra et al. 2015). However, we can briefly say that FDI is governed by four broad (and not mutually exclusive) motives: sell more, buy better (reduce costs of inputs), upgrade (increase the pool of assets that compounds the firm's source of competitive advantages) or escape (from an adverse environment at home country).
} 
by outlier-driven results. An early indication of this appeared in Choe (2003), in which the finding that FDI causes GDP growth (in the Granger sense) did not survive the exclusion of a few outliers. Even more concerning was Herzer's (2012) results, which suggested that, for most developing countries, FDI might be detrimental to long-run income level. ${ }^{6}$ On this point, we should note that the IB literature has embraced the FDI-GDP relationship somewhat uncritically, particularly within the investment development path, which is mistakenly used by commentators to be evidence that a certain level of FDI activity is associated with specific income levels (see Narula and Dunning 2010). Indeed, Narula and Dunning (2010, p. 265) note that

It is not entirely clear that there is a direct causality between FDI and development. Our view is that while a relationship exists between MNEs and development, there is a very large "black box" of intervening mechanisms and processes. Unless these intervening mechanisms between MNE activity and development are properly understood, all that can be said with certainty is that the determinants of FDI are also the determinants of development.

One might be tempted to conclude that there is little mileage in further macroeconomic studies on the development impacts of FDI. However, we believe that there is still much scope for studies in this line because many factors, such as institutional quality, corruption, regulatory policy and trade policy, are difficult to deal with at the firm level. The research agenda must go beyond the estimation of average effects of FDI on GDP growth, and allow for heterogeneity. Crucial to appreciating this at the macroeconomic level is that no two countries have the same endowments and resources, or history. Therefore, each country's investment development path is idiosyncratic (Narula 1996; Narula and Dunning 2010). Although the generalizability of findings is always a desirable feature of applied research, studies (Kottaridi and Stengos 2010; Herzer 2012) have shown that accounting for heterogeneous effects is essential to drawing sound conclusions. ${ }^{7}$ Studying the growth of countries and their interaction should ideally be done longitudinally, but such data is rarely available, and it is often punctuated by significant 'shocks' due to political, economic, technological and social upheaval. In many cases, especially in developing countries, reliable data is only recently becoming available, but this increase of the time dimension of FDI databases will allow modelling heterogeneity beyond simple interaction

\footnotetext{
${ }^{6}$ Herzer (2012) estimated the long-run relationship between GDP and FDI/GDP for a group of 44 developing countries over the period 1970-2005. The country-specific coefficients were negative for 26 countries (and statistically significant for 20 of these countries), indicating that increases in FDI/GDP ratio could have been detrimental to the GDP level in the long run for a substantial number of developing countries.

7 After estimating a cross-country GDP growth regression that allowed the estimation of observationspecific coefficients (using a semi-parametric model), Kottaridi and Stengos (2010, pp. 866-7) concluded that "it appears that the way FDI affects growth differs across and within countries. The relationship seems to be complex and the impact varies according to a country's level of FDI. (...) parameter heterogeneity may exist in the sense that the effect of a change in a particular variable is not the same. (...) In other words, there exists a different FDI-growth nexus in different countries".
} 
effects, making it feasible to adopt estimation techniques focused in long-run relationships instead of short-term effects.

Another element of heterogeneity that deserves further exploration is sectoral effects of FDI. Indeed, almost all the macroeconomic studies investigate the impact of FDI on aggregate growth. However, the impact of FDI is likely to vary across sectors and industries. A dollar of FDI offer quite different (potential) benefits depending on the sector/industry it goes to. Indeed, the development outcomes are contingent on both the sector/industry characteristics (levels of competition and verticalization, for example) and the recipient country's location advantages (Narula and Dunning 2000; 2010). Therefore, cross-country quantitative studies that take into account the sectoral distribution of output and employment, and their changes as a consequence of the activity of foreign MNEs, will enrich our knowledge about the impact of FDI in host economies. What we know about FDI and structural change empirically is still predominantly based on case studies. Although these case studies are important, the lack of quantitative studies makes it difficult to compare the experiences of different countries. To our knowledge, Alfaro and Charlton (2013) remains the only study that matched industry-level FDI and value-added data for a reasonably 'large' set of (29) countries. These results suggest that FDI is positively related to growth in the value added in the same industry/country. Furthermore, the effects are stronger for industries with higher skill requirements and for industries more reliant on external capital (equity). Nonetheless, as their sample was restricted to OECD economies, we do not know whether such results can be extended to developing countries. Therefore, studies following this approach, but with a focus on developing countries, would contribute to increase our knowledge of the impact of FDI at more disaggregate level.

The issue of FDI heterogeneity needs to be included in more macroeconomic studies by examining the characteristics of inward FDI at a more granular level. By using aggregate FDI stocks or flow, it is fairly easy to conclude that FDI is always good, if the estimates show a positive parameter for the effect of FDI on growth, or, on the contrary, that FDI is always harmful, if the coefficient is negative. ${ }^{8}$ That few studies do so is, to a large extent, due to the unavailability of data that uniformly characterize inward FDI across countries. However, a few studies have already explored this avenue, demonstrating that treating FDI as homogeneous is likely to hide important matters. Fortanier (2007) investigated the differential growth effects of FDI coming from six OECD economies (France, Germany, Japan, Netherlands, United Kingdom and United States). Her results indicated that, on average, FDI had a negative effect on GDP growth of recipient economies, but the effect of Japanese FDI was much more negative than the effects of FDI from other origins, what she attributed to marked differences in terms of sectoral distribution of outward FDI, ownership preferences, ways of internationalization, degree of vertical integration, level of local procurement, the intensity of the use of expatriation and MNEs'

\footnotetext{
${ }^{8}$ Although a (single) coefficient simply show the average effect of FDI on GDP growth, such type of extremist interpretation is not unlikely in a world where pressure groups try to push forward their own interests.
} 
strategies. Beugelsdijk et al. (2008) is another effort to account for FDI heterogeneity in cross-country growth studies, by using data on the destination of sales of the affiliates of US MNEs to distinguish between horizontal (market seeking) and vertical (efficiency seeking) FDI. According to their estimates, FDI has a positive effect on growth in developed countries, but horizontal FDI produce larger effects than vertical FDI. In developing countries, horizontal FDI does not affect growth, while vertical FDI has a negative effect, although not statistically significant. Although their empirical approach may be subject to criticism, since the US MNEs account for only a fraction of total inward FDI in host countries, it is an interesting way to test the hypothesis of differential impacts of FDI according to its characteristics.

We also believe that more studies should investigate the effects of FDI on other GDP growth determinants, such as domestic investment in physical capital and human capital as well as total factor productivity, instead of focusing solely on growth itself. Although there is a substantial literature that has investigated the effect of FDI on domestic investment, the evidence is quite inconclusive. While some studies have found that FDI tends to crowd out domestic investment in developing countries (Morrissey and Udomkerdmongkol 2012), others favour the view that increases in FDI leads to increases in domestic investment (Al-Sadig 2013; Farla et al. 2016). The available evidence also suggests a considerable variation in this relationship across regions. In the period 1970-2000, FDI crowded-out domestic investment in Latin America, while a crowding-in effect was observed in developing Asia, according to Agosin and Mayer (2000) and Agosin and Machado (2005). Crowding-out was also detected in Sub-Saharan Africa by Mutenyo et al. (2010), in the period 1990-2003.

With respect to the effects of FDI on other GDP growth determinants, studies are rare. One recent exception is Makiela and Ouattara (2018), which found that FDI flows have a positive effect on capital accumulation in both developed and developing countries, but its impact on total factor productivity growth is insignificant. We believe that this is a promising avenue for future research waiting to be exploredfor example, the investigation of the impact of FDI on GDP through changes in the structure of exports.

\section{Challenges for future research}

Over the last 60 years, the field of international business has evolved rapidly, although over the last 25 years it has also become relatively isolated from fields such as international trade, political economy, development and international finance. While IB's conceptual contributions have found their way to the empirical and conceptual work being done in the economics side of the literature-in particular, the efforts of Helpman (1984; 1985), Markusen (1984) and Ethier (1986) incorporated some of the features of the eclectic paradigm into conventional general equilibrium modelling - there is now little exchange between IB and these areas of research.

Future work on MNE-assisted development faces some common challenges, both within economics and IB. First, there is a common bias to a focus on FDI and not MNEs. FDI — as distinguished from foreign portfolio investment—mattered until the 
early 1990s, because control was synonymous with ownership, and this was assisted by the fact that balance of payments statistics are still collected to make this distinction. This simplistic distinction is no longer useful. Control can be exerted with decreasing levels of direct investment, as typified by the growth of global supply chains, value chains, or production networks. An anecdotal estimate is that the level of non-FDI associated MNE activity in Asia is roughly the same as FDI related level. In other words, to get a true estimate of the role of MNEs in Asian economies requires a doubling of the FDI stock levels. Empirical analysis depends critically on data, and when the data is off by such a large magnitude, it makes the results and conclusions thereof decreasingly relevant.

Second, data is rarely collected on FDI stocks. Stock data requires adjusting flows for reinvested earnings, intra-company loans, repatriated earnings and payments, and locally raised capital. Again, the exclusive reliance on flow data throws the data off by several orders of magnitude, as many countries (incorrectly) estimate stocks by aggregated flows.

Third, unclear industry classifications mean that companies such as Flextronics (which provide contract manufacturing services) are classified as services FDI, rather than manufacturing. The rapid growth of the services sector is not entirely about what we might consider to be traditional service sector activities (utilities, banking, finance, insurance, construction, which themselves are worthy of observation, because the direct and indirect effects of these activities are fundamentally different), but also of this 'misclassification'. In short, the growth of the non-equity modes, and GVCs may be reflected not as a growth of manufacturing but of services.

We raise again the spectre of global value chains, because both the IB and economics literature has been fairly lacklustre in addressing this phenomenon. Within the IB literature it is still largely shaped by Buckley's global factory approach (Buckley 2009), which informed the excellent UNCTAD's World Investment Report on non-equity modes and MNEs. We still have difficulties in dealing with non-equity modes of governance within mainstream theories - the simple continuing use of a negation term is a clear indication of this. Non-equity modes are not simply a mirror of FDI modes. Although internalization theory provides scope for a continuum of arrangements between arm's length transactions and full internalization, non-FDI modes are seldom the object of research. Thus, we clearly need a better understanding how firms exercise control over complex value chains without relevant capital commitment as a means to better capture the development effects of MNEs. A big challenge in this respect is how to construct databases that accurately reflect the productive assets, be they domestic or foreign-owned, under an MNE's umbrella.

The related issue of informal actors and economies has also remained painfully off the radar. The absence of growth (or the absence of evidence of growth) from MNE activity reflects the fact that in some economies a majority of economic activity is informally organised, even in the manufacturing sector. They are excluded from statistics, but more importantly, they have few growth prospects. MNEs are increasingly aware of compliance issues and are unwilling to use supplier firms that do not meet health and safety requirements (Narula 2018c). At the same time, informally organised actors are unable to expand because they cannot invest in productivity enhancing investments due to financial constraints, as they cannot access capital 
from banks. This means that MNEs are able to directly affect only a small part of the economy, although through value chains that engage with the informal economy their influence is likely to be much greater (Narula 2018c).

It is to be noted as well, that the benefits of MNE activity result in secondary and tertiary effects, which is to say, local supplier firms themselves seek inputs from other local firms, and not all of these are directly associated with production. These are known as consumption linkages, for instance, because workers spend their incomes on lunches, or because firms buy office supplies from unrelated companies. These 'benefits' are rarely considered, but can be significant, especially for smaller economies. They also vary by sector: Tourism investment projects, for instance, have fewer opportunities for higher-order linkages, with consumption linkages far outweighing forward or backward linkages (and consequent employment, fiscal, innovation or other spillovers being fairly small).

Indeed, as noted in this paper, while considerable effort in the academic literature is spent on quantifying the spillovers and externalities from MNE activity, the primary or 'direct' effects are less carefully studied, and even more dismayingly, the costs associated with reaping these benefits are rarely properly accounted for. Direct effects come from fiscal linkages (tax revenues, payments to workers, etc.), employment (quality and quantity), but also there are costs associated with the use of overstretched infrastructure. Limited electricity supply becomes a cost, not only for MNEs and their suppliers (who may have to invest in private generation) but also for society which experiences load-shedding. Bottlenecks in skilled human capital, for instance, means that foreign investments create system-wide shortages, and raise the costs for other actors in other industries. This means the state needs to take into account a wider variety of costs when handing out subsidies and incentives. Plainly speaking, careful cost/benefit analysis need to be done. The current view that there are almost always benefits from FDI needs to be moderated, because not all rents are costless when the opportunity costs of scarce resources are considered, especially in the longer term. Subsidies and incentives should be carefully measured against costs as well as benefits.

Structural change is an issue that is much neglected. Countries' comparative advantage evolves over time, and this means that policies and location advantages suited to a particular set of industries are no longer appropriate in the new dispensation. Structural change may be as simple as a shift from traditional, resource-intensive sectors to more knowledge intensive ones, as illustrated in a simple Lewisan dual economy model (Narula 2018b). Managing the shift (and these shifts rarely happen suddenly) means appreciating that countries $\mathrm{L}$ advantages, and the kinds of $\mathrm{O}$ advantages its firms specialise in need to be transitioned. The policies that leverage upgrading in (say) apparel, do not work as well in auto components. It is still a matter of some debate whether MNE investment can be a catalyst for modifying a country's economic structure, or whether extant economic structure shapes the kinds of investments firms make. The point we are making is that growth and the interaction with MNE activity is not linear or monotonic over time, because the economy itself is in a constant state of flux.

We have intentionally ignored the political economy aspect of the story for reasons of space. Although much has been said about the importance of institutions, 
and the importance of good governance and stable political systems, it is no straightforward process to resolve these at the host country level. Development requires as a sine qua non a variety of key L advantages (Narula 2018b). These include stable institutions, a certain minimum level of infrastructure (including skilled and semiskilled human capital), functional markets (or organisations that can overcome market failures) to provide financial capital and other crucial support activities, functional government agencies to ensure that these public goods are available to all economic actors fairly. The absence of these location-bound assets sharply limits the potential for growth from MNE activity. In the absence of a stable political economy, rents from MNEs are used for current consumption and are wastefully dissipated. Weak governments may also utilise rents to buy legitimacy. MNEs-like it or not-are not exogenous actors in the political economy but can become key players within it. MNEs - through their political inaction or action-can aggravate the feebleness/strength of formal institutions. Theoretically and empirically the literature has largely ignored the role of MNEs as political actors in their own right.

Finally, we must note a strong preference for the literature to focus on economic development, with a tendency to measure this at an aggregate level, most often focusing on income, and to a lesser extent, employment. This is myopic. The focus on income inequalities by the work of Piketty and associates helps highlight that aggregate incomes hide inequalities, and policies and awareness of inequalities (whether along the dimensions of gender, age, or geographical) are high on the policy agenda in most countries, in addition to poverty alleviation (Kolk et al. 2018). MNEs and host countries (or their key stakeholders) are increasingly concerned about the potential for negative consequences at the environmental and social arena. Although over the last decade scholars have started to pay attention to nonincome aspects of development, there is little beyond anecdotal evidence that this is a growing phenomenon, or that we have the tools to appreciate and evaluate the contribution of MNEs to these other facets of human development. Although most home and host countries have expressed support for the Sustainable Development Goals (SDGs) which incorporate such a view. Unfortunately, while the SDGs note other significant challenges associated with environmental and social governance, the enthusiasm thus far is less obvious in terms of concrete actions by governments and MNEs towards achieving these goals.

Acknowledgements André Pineli thanks the CAPES Foundation (Brazil) for the financial support of his PhD studies at the University of Reading.

Open Access This article is distributed under the terms of the Creative Commons Attribution 4.0 International License (http://creativecommons.org/licenses/by/4.0/), which permits unrestricted use, distribution, and reproduction in any medium, provided you give appropriate credit to the original author(s) and the source, provide a link to the Creative Commons license, and indicate if changes were made.

\section{References}

Abraham, F., Konings, J., \& Slootmaekers, V. (2010). FDI spillovers in the Chinese manufacturing sector: Evidence of firm heterogeneity. Economics of Transition, 18(1), 143-182. 
Abramovitz, M. (1986). Catching up, forging ahead, and falling behind. The Journal of Economic History, 46(2), 385-406.

Agosin, M., \& Machado, R. (2005). Foreign investment in developing countries: Does it crowd in domestic investment? Oxford Development Studies, 33(2), 149-162.

Agosin, M. \& Mayer, R. (2000). Foreign investment in developing countries: Does it crowd in domestic investment? UNCTAD Discussion Paper no. 146.

Alfaro, L., \& Charlton, A. (2013). Growth and the quality of foreign direct investment. In J. Stiglitz \& J. Lin (Eds.), The industrial policy revolution I. London: Palgrave Macmillan.

Alfaro, L., Chanda, A., Kalemli-Ozcan, S., \& Sayek, S. (2004). FDI and economic growth: The role of local financial markets. Journal of International Economics, 64, 89-112.

Al-Sadig, A. (2013). The effects of foreign direct investment on private domestic investment: Evidence from developing countries. Empirical Economics, 44(4), 1267-1275.

Anwar, S., \& Nguyen, L. (2011). Foreign direct investment and export spillovers: Evidence from Vietnam. International Business Review, 20, 177-193.

Arnold, J., \& Javorcik, B. (2009). Gifted kids or pushy parents? Foreign acquisitions and plant performance in Indonesia. Journal of International Economics, 79, 42-53.

Auty, R. (1994). Industrial policy reform in six large newly industrializing countries: The resource curse thesis. World Development, 22(1), 11-26.

Ayyagari, M., \& Kosova, R. (2010). Does FDI facilitate domestic entry? Evidence from the Czech Republic. Review of International Economics, 18(1), 14-29.

Balasubramanyam, V., Salisu, M., \& Sapsford, D. (1996). Foreign direct investment and growth in EP and IS countries. The Economic Journal, 106(1), 92-105.

Bellak, C. (2004). How domestic and foreign affiliates differ and why does it matter? Journal of Economic Surveys, 18(2), 1-32.

Beugelsdijk, S., Smeets, R., \& Zwinkels, R. (2008). The impact of horizontal and vertical FDI on host's country economic growth. International Business Review, 17, 452-472.

Blalock, G., \& Simon, D. (2009). Do all firms benefit equally from downstream FDI? The moderating effect of local suppliers' capabilities on productivity gains. Journal of International Business Studies, 40, 1095-1112.

Blomstrom, M., \& Sjoholm, F. (1999). Technology transfer and spillovers: Does local participation with multinationals matter? European Economic Review, 43, 915-923.

Borensztein, E., De Gregorio, J., \& Lee, J. (1998). How does foreign direct investment affect economic growth? Journal of International Economics, 45, 115-135.

Buckley, P. (2009). The impact of the global factory on economic development. Journal of World Business, 44(2), 131-143.

Cantwell, J., \& Mudambi, R. (2005). MNE competence-creating subsidiary mandates. Strategic Management Journal, 26, 1109-1128.

Carkovic, M., \& Levine, R. (2005). Does foreign direct investment accelerate economic growth? In T. Moran, et al. (Eds.), Does foreign direct investment promote development?. Washington, DC: Institute for International Economics.

Castellani, D. (2012). In praise of pecuniary externalities. The European Journal of Development Research, 24(1), 15-19.

Castillo, L., Salem, D., \& Moreno, J. (2014). Foreign direct investment and productivity spillovers: Firmlevel evidence from Chilean industrial sector. Latin American Business Review, 15(2), 93-122.

Caves, R. (1974). Multinational firms, competition, and productivity in host-country markets. Economica, 41(162), 176-193.

Chen, C., Cheng, Y., \& Findlay, C. (2013). Export spillovers of FDI on China's domestic firms. Review of International Economics, 21(5), 841-856.

Choe, J. (2003). Do foreign direct investment and gross domestic investment promote economic growth? Review of Development Economics, 7(1), 44-57.

Chudnovsky, D., Lopez, A., \& Rossi, G. (2008). Foreign direct investment spillovers and the absorptive capabilities of domestic firms in the Argentine manufacturing sector (1992-2001). Journal of Development Studies, 44(5), 645-677.

Cieslik, A., \& Hagemejer, J. (2014). Multinational enterprises, absorptive capacity and export spillovers: evidence from Polish firm-level data. Review of Development Economics, 18(4), 709-726.

Cohen, W., \& Levinthal, D. (1989). Innovation and learning: The two faces of R\&D. The Economic Journal, 99, 569-596. 
Criscuolo, P., \& Narula, R. (2008). A novel approach to national technological accumulation and absorptive capacity: Aggregating Cohen and Levinthal. The European Journal of Development Research, 20(1), 56-73.

Cuervo-Cazurra, A., Narula, R., \& Un, C. (2015). Internationalization motives: Sell more, buy better, upgrade and escape. Multinational Business Review, 23(1), 25-35.

Driffield, N., \& Love, J. (2007). Linking FDI motivation and host economy productivity effects: Conceptual and empirical analysis. Journal of International Business Studies, 38, 460-473.

Dunning, J. (1988). The eclectic paradigm of international production: a restatement and some possible extensions. Journal of International Business Studies, 18, 1-31.

Dunning, J., \& Narula, R. (1996). Foreign direct investment and governments: Catalysts for economic restructuring. Basingstoke: Edward Elgar.

Duran, I., \& Ryan, M. (2014). Spillover effects from inward FDI and the exporting decisions of Chilean manufacturing plants. Journal of Industry, Competition and Trade, 14, 393-414.

Durham, J. (2004). Absorptive capacity and the effects of foreign direct investment and equity foreign portfolio investment on economic growth. European Economic Review, 48, 285-306.

Eapen, A. (2013). FDI spillover effects in incomplete datasets. Journal of International Business Studies, 44(7), 719-744.

Ethier, W. (1986). The multinational firm. Quarterly Journal of Economics, 80, 805-833.

Farla, K., de Crombrugghe, D., \& Verspagen, B. (2016). Institutions, foreign direct investment, and domestic investment: crowding out or crowding in? World Development, 88, 1-9.

Ferragina, A. (2014). Foreign ownership, survival and growth dynamics in Turkish manufacturing. In A. Ferragina, et al. (Eds.), Innovation, globalization and firm dynamics. Abingdon: Routledge.

Fortanier, F. (2007). Foreign direct investment and host country economic growth: Does the investor's country of origin play a role? Transnational Corporations, 16(2), 41-76.

Girma, S., Gong, Y., Gorg, H., \& Lancheros, S. (2015). Estimating direct and indirect effects of foreign direct investment on firm productivity in the presence of interactions between firms. Journal of International Economics, 95, 157-169.

Gorg, H., \& Greenaway, D. (2004). Much ado about nothing? Do domestic firms really benefit from foreign direct investment? The World Bank Research Observer, 19(2), 171-197.

Ha, Y., \& Giroud, A. (2015). Competence-creating subsidiaries and FDI technology spillovers. International Business Review, 24, 605-614.

Havranek, T., \& Irsova, Z. (2011). Estimating vertical spillovers from FDI: Why results vary and what the true effect is. Journal of International Economics, 85(2), 234-244.

Helpman, E. (1984). A simple theory of international trade with multinational corporations. Journal of Political Economy, 92(3), 451-471.

Helpman, E. (1985). Multinational corporations and trade structure. Review of Economic Studies, 52(3), $443-457$.

Herzer, D. (2012). How does foreign direct investment really affect developing countries' growth? Review of International Economics, 20(2), 396-414.

$\mathrm{Hu}$, A., \& Jefferson, G. (2009). A great wall of patents: What is behind China's recent patent explosion? Journal of Development Economics, 90, 57-68.

Irsova, Z., \& Havranek, T. (2013). Determinants of horizontal spillovers from FDI: Evidence from a large meta-analysis. World Development, 42, 1-15.

Ito, B., Yashiro, N., Xu, Z., Chen, X., \& Wakasugi, R. (2012). How Chinese industries benefit from FDI spillovers? China Economic Review, 23, 342-356.

Javorcik, B., \& Spatareanu, M. (2008). To share or not to share: Does local participation matter for spillovers from foreign direct investment? Journal of Development Economics, 85, 194-217.

Javorcik, B., \& Spatareanu, M. (2011). Does it matter where you come from? Vertical spillovers from foreign direct investment and the origin of investors. Journal of Development Economics, 96(1), 126-138.

Jindra, B., Giroud, A., \& Scott-Kennel, J. (2009). Subsidiary roles, vertical linkages and economic development: Lessons from transition economies. Journal of World Business, 44, 167-179.

Kokko, A., \& Thang, T. (2014). Foreign direct investment and the survival of domestic private firms in Viet Nam. Asian Development Review, 31(1), 53-91.

Kolk, A., Rivera-Santos, M., \& Rufin, C. (2018). Multinationals, international business and poverty: A cross-disciplinary research overview and conceptual framework. Journal of International Business Policy, 1(1), 92-115. 
Kosova, R. (2010). Do foreign firms crowd out domestic firms? Evidence from the Czech Republic. The Review of Economics and Statistics, 92(4), 861-881.

Kottaridi, C., \& Stengos, T. (2010). Foreign direct investment, human capital and non-linearities in economic growth. Journal of Macroeconomics, 32, 858-871.

Lall, S. (1996). Learning from the Asian Tigers: Studies in technology and industrial policy. Basingstoke: Macmillan.

Lall, S., \& Streeten, P. (1977). Foreign investment, transnationals and developing countries. London: Macmillan.

Lenaerts, K. \& Merlevede, B. (2014). FDI spillovers and multinational firm heterogeneity. Universiteit Gent Faculteit Economie en Bedrijfskunde Working Paper no. 879.

Liu, X., \& Buck, T. (2007). Innovation performance and channels for international technology spillovers: Evidence from Chinese high-tech industries. Research Policy, 36, 355-366.

Liu, Q., Lu, R., \& Qiu, L. (2017). Foreign acquisitions and target firms' performance in China. The World Economy, 40(1), 2-20.

Lu, Y., Tao, Z., \& Zhu, L. (2017). Identifying FDI spillovers. Journal of International Economics, 107, 75-90.

Makiela, K. \& Ouattara, B. (2018). Foreign direct investment and economic growth: Exploring the transmission channels. Economic Modelling, 72, 296-305.

Marin, A., \& Bell, M. (2006). Technology spillovers from foreign direct investment (FDI): The active role of MNC subsidiaries in Argentina in the 1990s. Journal of Development Studies, 42(4), 678-697.

Marin, A., \& Sasidharan, S. (2010). Heterogeneous MNC subsidiaries and technological spillovers: Explaining positive and negative effects in India. Research Policy, 39, 1227-1241.

Markusen, J. (1984). Multinationals, multi-plant economies, and the gains from trade. Journal of International Economics, 16, 205-226.

Mayneris, F. \& Poncet, S. (2011). Entry on difficult export markets by Chinese domestic firms: The role of foreign export spillovers. CEPII Working Paper no. 32.

Mayneris, F., \& Poncet, S. (2015). Chinese firms' entry to export markets: The role of foreign export spillovers. The World Bank Economic Review, 29(1), 150-179.

Merlevede, B. \& Schoors, K. (2009). Openness, competition, technology and FDI spillovers: Evidence from Romania (Unpublished).

Meyer, K., \& Sinani, E. (2009). When and where does foreign direct investment generate positive spillovers? A meta-analysis. Journal of International Business Studies, 40, 1075-1094.

Moran, T. (2011). Foreign direct investment and development: Launching a second generation of policy research: Avoiding the mistakes of the first, reevaluating policies for developed and developing countries. Washington, DC: Peterson Institute for International Economics.

Morrissey, O. (2012). FDI in sub-Saharan Africa: Few linkages, fewer spillovers. European Journal of Development Research, 24(1), 26-31.

Morrissey, O., \& Udomkerdmongkol, M. (2012). Governance, private investment and foreign direct investment in developing countries. World Development, 40(3), 437-445.

Mutenyo, J., Asmah, E., \& Kalio, A. (2010). Does foreign direct investment crowd-out domestic private investment in Sub-Saharan Africa? African Finance Journal, 12(1), $27-52$.

Narula, R. (1996). Multinational investment and economic structure: Globalisation and competitiveness. London: Routledge.

Narula, R. (2014a). Exploring the paradox of competence-creating subsidiaries: Balancing bandwidth and dispersion in MNEs. Long Range Planning, 47(1-2), 4-15.

Narula, R. (2014b). Foreign direct investment as a driver of industrial development: Why is there so little evidence? In R. Van Tulder, A. Verbeke, \& R. Strange (Eds.), International business and sustainable development (Progress in International Business Research, Volume 8). Emerald: Bingley.

Narula, R. (2018a). Multinational firms and the extractive sectors in the 21st century: Can they drive development? Journal of World Business, 53(1), 85-91.

Narula, R. (2018b). An extended dual economy model: Implications for emerging economies and their multinational firms. International Journal of Emerging Markets, 13(3), 586-602.

Narula, R. (2018c). CSR initiatives in global value chains and unintended consequences for development. Reading: Mimeo, University of Reading.

Narula, R., \& Driffield, N. (2012). Does FDI cause development? The ambiguity of the evidence and why it matters. The European Journal of Development Research, 24(1), 1-7.

Narula, R., \& Dunning, J. (2000). Industrial development, globalization and multinational enterprises: New realities for developing countries. Oxford Development Studies, 28(2), 141-167. 
Narula, R., \& Dunning, J. (2010). Multinational enterprises, development and globalization: Some clarifications and a research agenda. Oxford Development Studies, 38(3), 263-287.

Narula, R. \& Marin, A. (2003) Foreign direct investment spillovers, absorptive capacities and human capital development: Evidence from Argentina. Geneva: International Labour Office Working Paper no. 96.

Narula, R., \& Pineli, A. (2017). Multinational enterprises and economic development in host countries: What we know and what we don't know. In G. Giorgioni (Ed.), Development finance: Challenges and opportunities. London: Palgrave.

Ni, B., Spatareanu, M., Manole, V., Otsuki, T., \& Yamada, H. (2015). How will the origin of FDI affect domestic firms' TFP? Evidence from Vietnam. FREIT Working Paper no. 74.

Ni, B. (2016). Productivity gap and vertical spillover: Evidence from Vietnam. Osaka: Graduate School of Economics and Osaka School of International Public Policy Discussion Paper no. 4.

Reddaway, W., Potter, S. \& Taylor, C. (1968). Effects of U.K. direct investment overseas: Final report. Cambridge: Cambridge University (Department of Applied Economics Occasional Paper no. 15).

Reuber, G. (1973). Private foreign investment in development. Oxford: Clarendon Press.

Sagafi-Nejad, T. (2008). The UN and transnational corporations: From code of conduct to global compact. Bloomington: Indiana University Press.

Smeets, R., \& de Vaal, A. (2016). Intellectual property rights and the productivity effects of MNE affiliates on host-country firms. International Business Review, 25, 419-434.

Swenson, D., \& Chen, H. (2014). Multinational exposure and the quality of new Chinese exports. Oxford Bulletin of Economics and Statistics, 76(1), 41-66.

Taymaz, E., \& Ozler, S. (2007). Foreign ownership, competition, and survival dynamics. Review of Industrial Organization, 31, 23-42.

Todo, Y., \& Miyamoto, K. (2006). Knowledge spillovers from foreign direct investment and the role of local R\&D activities: Evidence from Indonesia. Economic Development and Cultural Change, 55(1), 173-200.

Tybout, J. (2000). Manufacturing firms in developing countries: How well do they do, and why? Journal of Economic Literature, 38, 11-44.

UNCTAD_United Nations Conference on Trade and Development. (2013). World Investment Report 2013: Global value chains: Investment and trade for development. New York and Geneva: United Nations.

UNCTAD_United Nations Conference on Trade and Development. (2018). World Investment Report 2018: Investment and new industrial policies. New York and Geneva: United Nations.

UNDESA-United Nations Department of Economic and Social Affairs. (1973). Multinational corporations in world development. New York: United Nations.

Venables, A. (2016). Using natural resources for development: Why has it proven so difficult. Journal of Economic Perspectives, 30(1), 161-184.

Wooster, R., \& Diebel, D. (2010). Productivity spillovers from foreign direct investment in developing countries: A meta-regression analysis. Review of Development Economics, 14(3), 640-655.

World Bank, World Development Indicators. (2017). Research and development expenditure (\% of GDP). https://data.worldbank.org/indicator/GB.XPD.RSDV.GD.ZS. Accessed 8 Jun 2018. 